\title{
PROGNOSTIC SIGNIFICANCE OF RADIATION INDUCED LYMPHOPENIA IN PATIENTS WITH HIGH RISK PROSTATE CANCER
}

\author{
KATARINA ANTUNAC ${ }^{1}$, PETAR SUTON ${ }^{1}$ and SARA BILIĆ-KNEŽEVIĆ ${ }^{2}$ \\ ${ }^{1}$ Division of Radiotherapy and Medical Oncology, University Hospital for Tumors, \\ Sestre milosrdnice University Hospital Center, Zagreb, Croatia; \\ ${ }^{2}$ Department of Oncology and Nuclear Medicine, General Hospital Zadar, Zadar, Croatia
}

\begin{abstract}
Summary
Lymphopenia is a known side-effect of radiotherapy but, being usually asymptomatic, its clinical value is just recently being recognized in the light of immunotherapy revival. Here we present clinical and laboratory data of 9 high-risk prostate patients that underwent whole pelvis radiotherapy combined with hormonal therapy. All patients experienced haematological toxicity during their treatment, with lymphopenia being the most profound. In addition, all of them were asymptomatic as regards to observed lymphopenia. After median follow up of 17 months 8/9 patients are still receiving hormonal treatment and have no evidence of their disease. The only patient with relapse discontinued hormonal therapy upon completion of radiotherapy. Therefore, we could not show any detrimental effect of observed lymphopenia on the outcome of these 9 patients.
\end{abstract}

KEY WORDS: prostate cancer, whole pelvis radiotherapy, radiation induced lymphopenia

\section{PROGNOSTIČKI ZNAČAJ ZRAČENJEM INDUCIRANE LIMFOPENIJE KOD BOLESNIKA S RAKOM PROSTATE VISOKOG RIZIKA}

\section{Sažetak:}

Limfopenija je poznata nuspojava zračenja, međutim, kako je obično asimptomatska, njen klinički značaj je tek odnedavno prepoznat s obzirom na rastući interes za imunoterapijom. Predstavljamo kliničke i laboratorijske podatke 9 bolesnika s rakom prostate visokog rizika kod kojih je provedeno zračenje zdjelice u kombinaciji s hormonskom terapijom. Kod svih bolesnika je zabilježena hematološka toksičnost; limfopenija je bila najviše izražena. Sve opažene limfopenije su bile asimptomatske. Nakon medijana praćenja od 17 mjeseci 8 od 9 bolesnika je bez znakova bolesti te još primaju hormonsku terapiju. Jedini bolesnik s relapsom bolesti je prestao dobivati hormonsku terapiju po završetku zračenja. Sukladno navedenom, nismo uspjeli pokazati štetan učinak opažene limfopenije na ishod liječenja ovih 9 bolesnika.

KLJUČNE RIJEČI: rak prostate, zračenje zdjelice, limfopenija uzrokovana zračenjem

\section{INTRODUCTION}

Haematological toxicity from post-prostatectomy whole pelvis radiotherapy has been described in literature. Lymphopenia has been observed with standard fractionation (daily fractions of $1.8-2 \mathrm{~Gy})$ and neutropenia with hypofractionation (daily fractions $>2$ Gy) (1). Lymphopenia is defined as a peripheral blood lymphocyte count $<1.5 \times 10^{9} / \mathrm{L}$. Since lymphocytes account for about $20-40 \%$ of overall white blood counts, it cannot be 
Lib Oncol. 2018;46(2-3):55-59

Table 1

PATIENTS' CHARACTERISTICS

\begin{tabular}{|c|c|c|c|c|c|}
\hline Age & $\begin{array}{l}\text { Pre-therapeutic } \\
\text { PSA value }(\mathrm{ng} / \mathrm{mL})\end{array}$ & GS & Hormonal therapy & $\begin{array}{l}\text { Follow up upon completion } \\
\text { of radiotherapy }\end{array}$ & PSA level/outcome \\
\hline 77 & 11.95 & $4+5$ & LHRH agonist & 21 months & $0.01 / \mathrm{NED}^{\mathrm{a}}$ \\
\hline 82 & 53.04 & $3+5$ & LHRH agonist & 9 months & 0.92/NED \\
\hline 84 & 29.53 & $4+3$ & Bicalutamide $150 \mathrm{mg}$ & 12 months & 0.05/NED \\
\hline 66 & 38.22 & $4+3$ & LHRH agonist & 9 months & 0.01/NED \\
\hline 77 & $>100$ & $3+4$ & Bicalutamide $150 \mathrm{mg}$ & 20 months & 0.04/NED \\
\hline 76 & 52.73 & $3+4$ & $\begin{array}{l}\text { Bicalutamide } 150 \mathrm{mg} \\
\text { (for } 3 \text { months, before } \\
\text { and during RT) }\end{array}$ & 17 months & $\begin{array}{l}\text { Biochemical relapse after } 14 \text { months (PSA } \\
\text { 3.73), bone and lymph node metastases } 2 \\
\text { months later (PSA 7.18) /AWD }\end{array}$ \\
\hline 70 & 53.41 & $3+3$ & LHRH agonist & 19 months & 0.04/NED \\
\hline 72 & 31 & $3+4$ & LHRH agonist & 15 months & $<0.01 /$ NED \\
\hline 82 & 7.15 & $4+4$ & LHRH agonist & 21 month & $<0.002 /$ NED \\
\hline
\end{tabular}

${ }^{a}$ No evidence of disease

${ }^{\mathrm{b}}$ Alive with disease

detected without differential blood count. Lymphocytes are the most radiosensitive cells among erythroid, myeloid and lymphoid lineage (2). Lymphocytes staying within or circulating through a radiation portal are affected by radiotherapy; their lethal dose (LD) 50 is 2 Gy and LD90 3 Gy. Other haematological side effects such as thrombocytopenia, neutropenia or anemia are much more studied compared to lymphopenia given their clinically apparent and acute influence on patients, making them prone to bleeding, infections or fatigue. Effect of radiation on lymphocyte counts has been known for decades (3) but just recently is its potential association with tumour control and patient outcomes being researched, bearing in mind the role of immune system on tumour surveillance.

Aim of this analysis was to address severity and duration of haematological toxicity from whole pelvis radiotherapy in high- risk prostate cancer and its effect on tumour control. Whole pelvis radiotherapy is indicated in patients with high risk prostate cancer, when, according to nomogram, risk of metastases in pelvic lymph nodes exceeds $15 \%$. Clinical target volume should include presacral lymph nodes, lymph nodes around iliac vessels and obturator lymph nodes (3). Usual prescribed dose, according to our institutional guidelines, is $46 \mathrm{~Gy}$ on pelvic lymph nodes (PTV1), 56 Gy on seminal vesicles (PTV2) and 74 Gy on prostate (PTV3), standard fractionation. Irradiation starts with all 3 target volumes; therefore all patients receive irradiation of their pelvis during first 5 weeks of treatment.

\section{PATIENTS AND METHODS}

We have monitored the counts of absolute white blood cells, lymphocytes, neutrophils, platelets and heamoglobin in 9 patients with high risk prostate cancers undergoing whole pelvis radiotherapy. All 9 patients were irradiated in 2016 and 2017 at University Hospital for Tumours, Zagreb. Patients' characteristics are shown in Table 1. Median patient age was 77 years (range 66-84), initial PSA values were between 7.15 and $>100 \mathrm{ng} / \mathrm{mL}, 1$ patient had prostate adenocarcinoma Gleason score (GS) 3+3, Grade group (GG) 1, 3 patients GS 3+4, GG 2, 2 patients GS 4+3, gg 3, 1 patient GS 3+5, GG 4, 1 patient GS4+4, GG 4, and 1 patient GS 4+5, GG 5. Median follow up (upon completion of radiotherapy) was 17 months (range 9- 21 months).

All baseline blood counts values were within normal ranges. Prescribed dose on pelvic lymph nodes was 46Gy, on seminal vesicles $56 \mathrm{~Gy}$ and on prostate 74 Gy, 2 Gy per fraction, 5 days/week. Radiation portals are shown on Figures 1 and 2. In all patients treatment started with whole pelvis irradiation. All patients received androgen deprivation therapy; 3 patients received antiandrogen only (bicalutamide $150 \mathrm{mg}$ ) and 6 patients LHRH agonist with antiandrogen (flutamide 3x $250 \mathrm{mg}$ or bicalutamide $50 \mathrm{mg}$ ) before and during radio- 


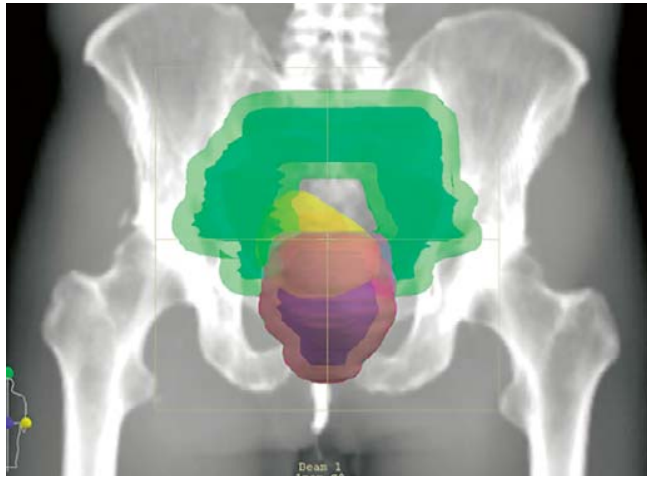

Figure 1 and 2 Radiation portals

therapy. Complete blood sample was obtained before the beginning of radiotherapy and then weekly during the treatment.

\section{RESULTS}

In all patients persistent decline of absolute white blood cells count (WBC) and haemoglobin level $(\mathrm{Hb}$ ) was observed (WBC till 3.28x 10\%/L, $\mathrm{Hb}$ till $104 \mathrm{~g} / \mathrm{L})$ (Charts 1 and 2). No change in neutrophil and platelet counts was noticed. A significant decline of lymphocyte count was observed in all patients, both in absolute values and percentage, with nadir values between 0.39 and $0.79 \times 10^{9} / \mathrm{L}$

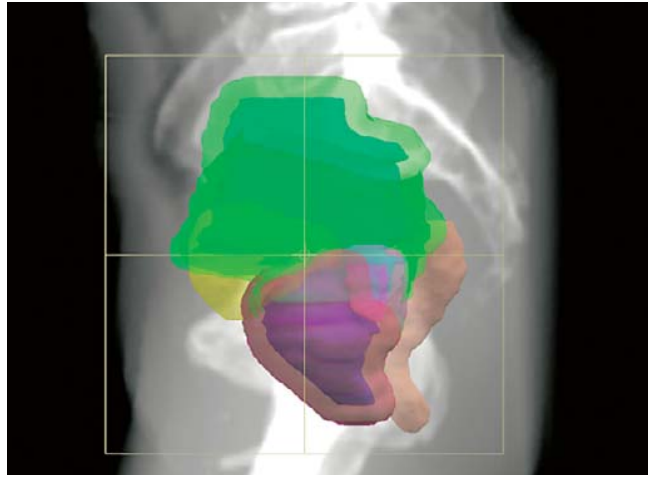

(median 0.54x 109/L) (Chart 3). Lymphopenias occurred from 5th week of radiotherapy onwards, with doses ranging from 44 to 66 Gy (median being $52 \mathrm{~Gy}$ ), hence 30 till 45 days from the beginning of whole pelvis radiotherapy (median 36th day). By the end of radiotherapy lymphocyte counts gradually increased, but without reaching referral values (1.19- 3.35x 10\%/L). All observed lymphopenias were asymptomatic, both during and upon completion of radiation treatment.

After a median follow up of 17 months, 8 patients are without evidence of their disease and all of them are still receiving hormonal treatment: two patient bicalutamide and 6 patients LHRH

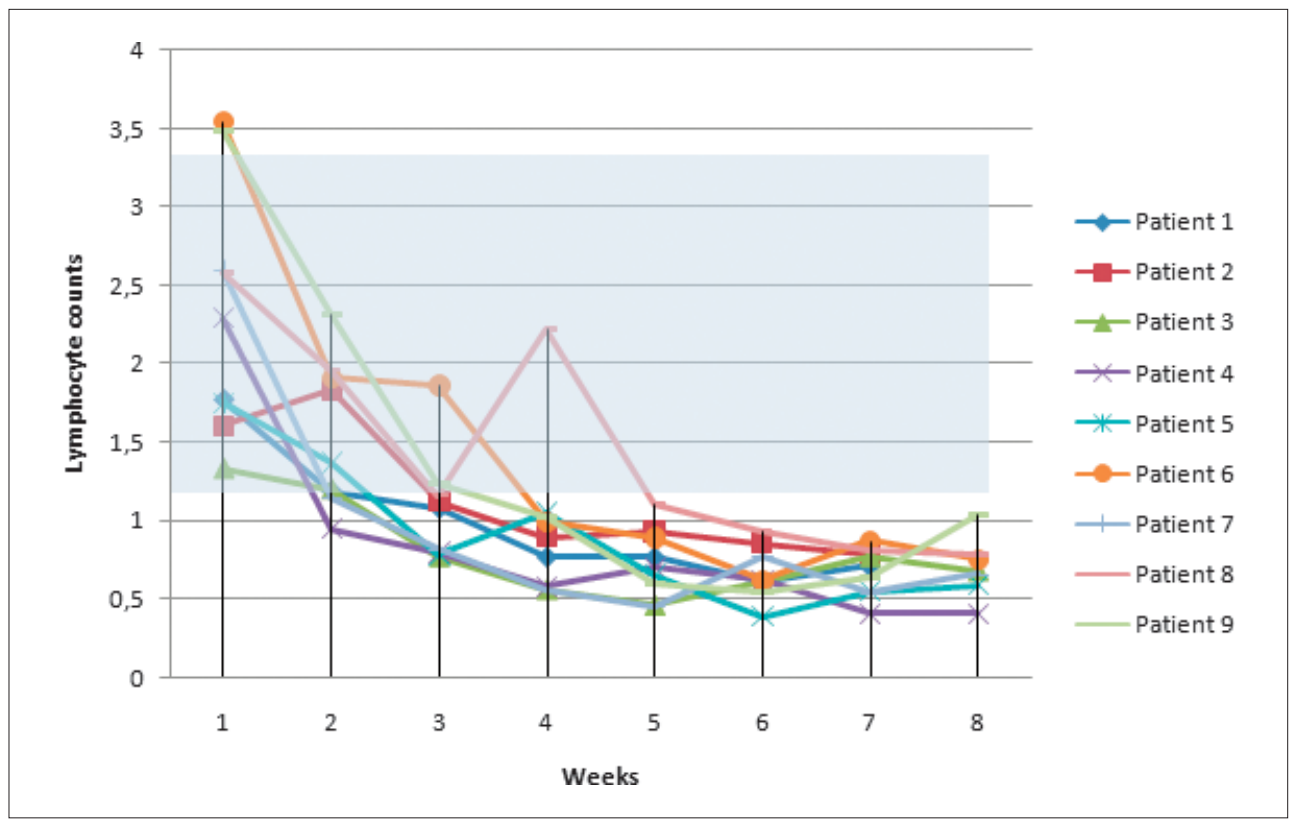

Chart 1 Lymphocyte counts (referent value range marked with blue) 


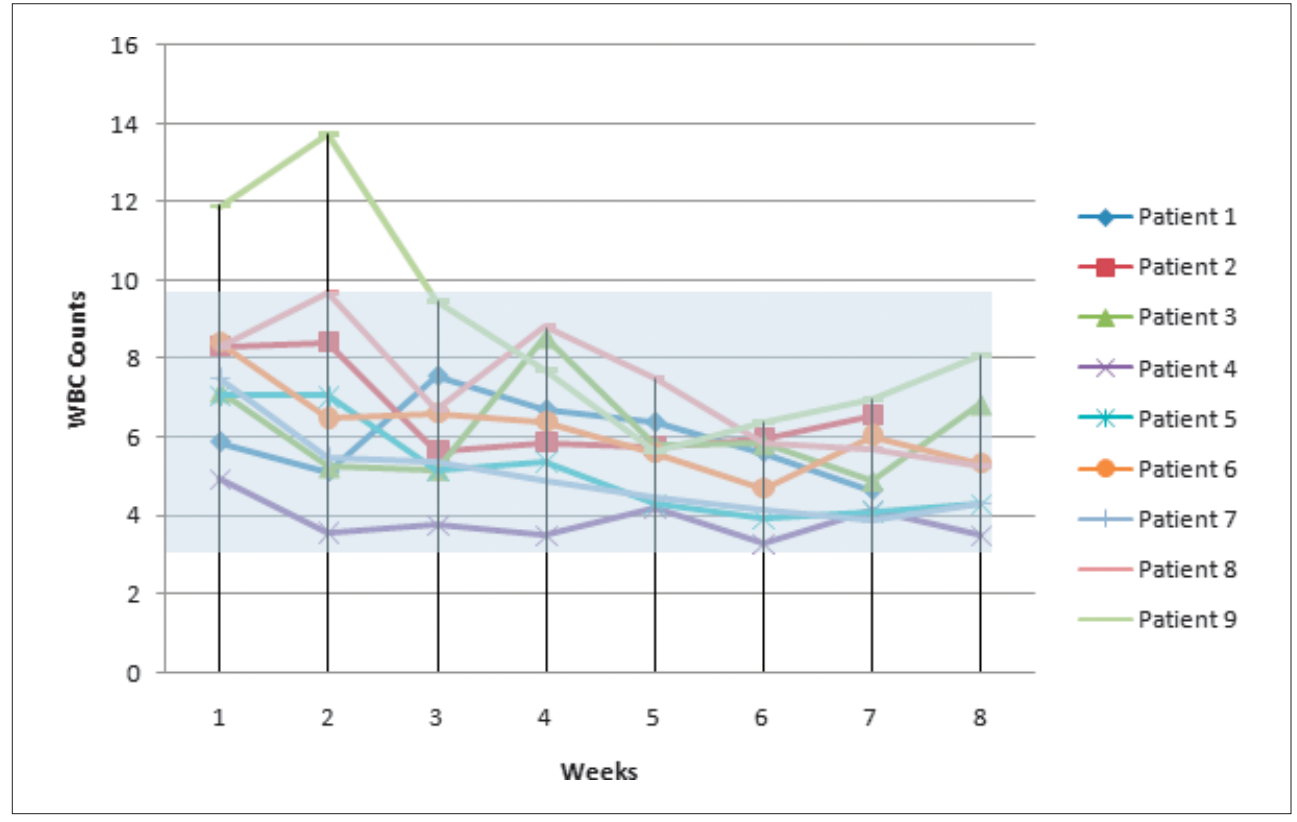

Chart 2 WBC counts (referent value range marked with blue)

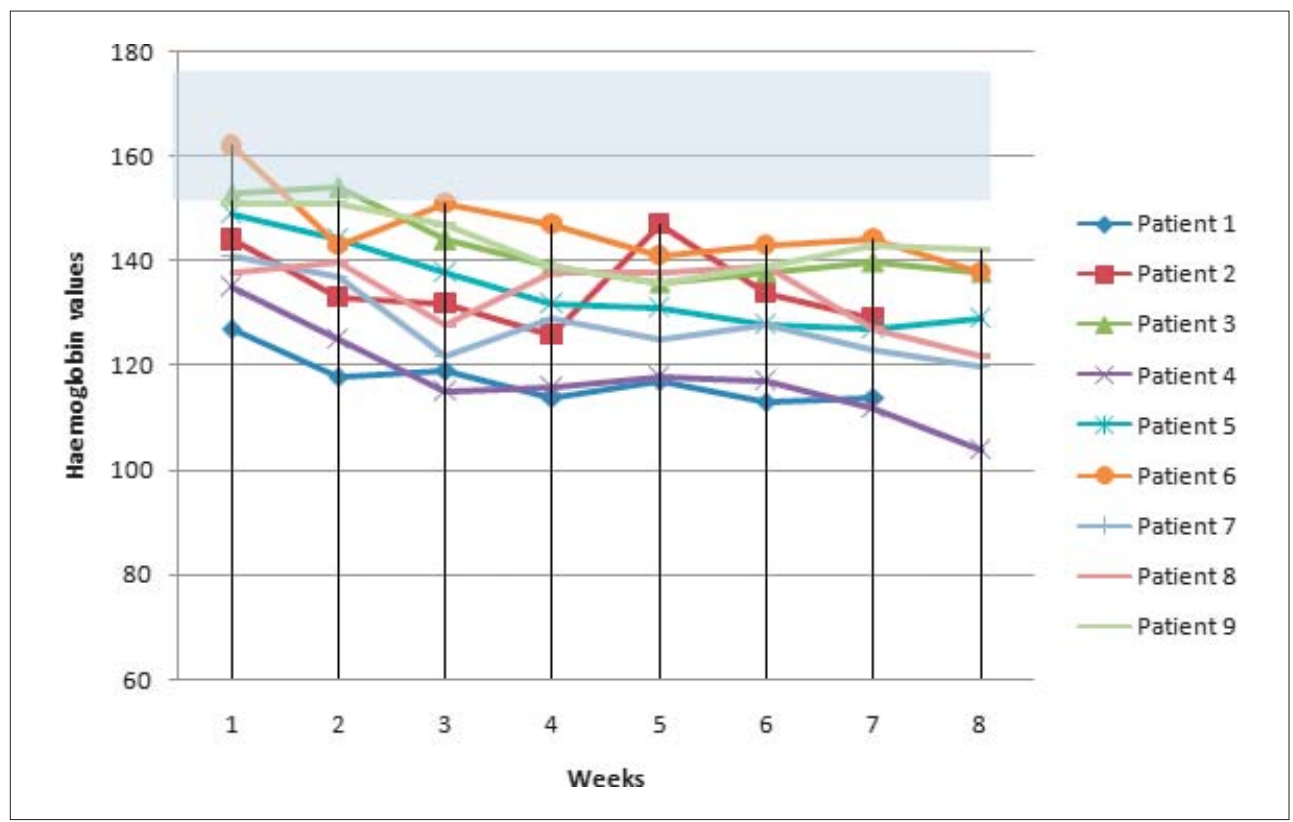

Chart 3 Haemoglobin value $(g / L)$, (referent value range marked with blue)

agonist. One patient had biochemical relapse after 14 months and 2 months later positron emission tomography (PET) scan revealed bone and lymph node metastases. That patient discontinued hormonal treatment with bicalutamide after completion of radiotherapy.

\section{DISCUSSION}

Although well-known for decades, effect of radiation on lymphocyte counts has recently become more and more interesting, following immunotherapy revival. Lower number of circulat- 
ing lymphocytes could be associated to lower tumour lymphocyte infiltration and weaker immunological anti- tumour response, all of which could translate into worse outcome.

According to literature data, association of treatment induced lymphopenias and worse outcome was observed in patients with glioblastoma, head and neck squamous cancer, nasopharyngeal cancer, both non-small and small cell lung cancer, pancreatic cancer, oesophageal cancer and breast cancer (2).

As far as pelvic malignancies are concerned, two trials found association between lymphopenia and worse outcome, both in patients with cervical cancer undergoing chemoradiotherapy. $\mathrm{Wu}$ et al. found threshold lymphocyte value of $<0.5$ cells $/ \mathrm{mm}^{3} 2$ months upon completion of the treatment being associated with worse median overall survival: 21.2 vs 45.0 months, $\mathrm{P}=0.03$ (5). Cho and al. analysed 124 patients with FIGO stage I-III cervical cancer who received weekly cisplatin-based concomitant chemoradiotherapy and brachytherapy. Patients with lymphopenia gr 2-3 had 5-year disease specific survival (DSS) and 3-year progression specific survival (PFS) significantly higher compared to those with grade 4 lymphopenia (defined as $<200$ cells/1): $84.8 \%$ vs. $50.4 \%$, p $<0.001$, and $80.7 \%$ vs. $50 \%$, p $=0.002$, respectively (6).

Our patients did not receive concurrent chemotherapy, which is known to also have an effect on lymphocyte counts. Since all of them experienced lymphopenia, we could not make any clear conclusion on its effect on their outcome. The only patient that had disease recurrence discontinued hormonal treatment upon completion of radiotherapy. Overall his hormonal therapy lasted for 3 months, which is in contrast with recommended duration of two to three years for this subset of patients.

\section{CONCLUSION}

Clinically unapparent lymphopenia occurred in all 9 patients during radiotherapy, starting from
30 to 45 days from the beginning of the treatment. After median follow up of 17 months 8/9 patients are without evidence of the disease. Although patient sample is quite small and follow up is short, it can still be concluded that lymphopenia did not have any effect on tumour control. One relapse should rather be attributed to hormonal therapy discontinuation than to changes in immunological anti- tumour effect caused by radiation induced lymphopenia.

\section{LITERATURE:}

1. Cozzarini C, Fiorino C, Chiorda B N. et al. Hematologic toxicity from post-prostatectomy whole pelvis $\mathrm{RT}$ is not negligible and prolonged. A prospective study. ESTRO 33, Vienna-Austria. Radioter Oncol 2014;111(suppl1):S32-S33.

2. Venkatesulu B P, Mallick S, Lin S H et al. A systematic review of the influence of radiation-induced lymphopenia on survival outcomes in solid tumour. Critical Reviews in Oncology/Haematology 2018;123: 42-51.

3. Campbell A C, Wiernik G, Wood J et al. Characteristics of lymphopenia induced by radiotherapy. Clin Exp Immunol. 1976;23:200-208.

4. https://www.rtog.org/CoreLab/ContouringAtlases/ ProstatePelvicLymphNodes.aspx Accessed on: 03. May 2018.

5. Wu E S, Oduyebo T, Cobb L P et al. Lymphopenia and its association with survival in patients with locally advanced cervical cancer. Gynecol Oncol. 2016;140(1): 76-82.

6. Cho O, Chun M, Chang S J et al. Prognostic value of severe lymphopenia during pelvic concurrent chemoradiotherapy in cervical cancer. Anticancer Research. 2106;36(7):3541-3547.

Corresponding author: Katarina Antunac, Division of Radiotherapy and Medical Oncology, University Hospital for Tumors, Sestre milosrdnice University Hospital Center, Ilica 197, 10000 Zagreb, Croatia. e-mail: katarina. antunac@zg.htnet.hr 